\title{
SURVEY OF BASIC TECHNICAL SKILLS OF TABLE TENNIS GAME ATHLETES PTMSI PUSLATKAB BANGKALAN
}

\author{
Khoirul Anwar $^{1}$, Heni Yuli Handayani ${ }^{2}$, Agus Himawan ${ }^{3}$ \\ STKIP PGRI Bangkalan ${ }^{1}$, STKIP PGRI Bangkalan ${ }^{2}$, STKIP PGRI Bangkalan ${ }^{3}$ \\ khoirul@stkippgri-bkl.ac.id
}

\begin{abstract}
This study aims to determine the level of basic technical skills of table tennis athletes at PTMSI Pusat Kab Bangkalan. The method chosen and the research used a survey. Saturated samples were taken from all table tennis athletes at the Bangkalan puslatkab totaling 4 athletes. Measuring the skill level of the basic table tennis game techniques, namely Service Techniques (Serve), Attack Techniques (Attacking), Defense Techniques (Block), Drive Punch Techniques, Push Punch Techniques, Flick Techniques, and Chop Techniques for athletes at the Bangkalan sports center using tests and measurements . Researchers collected data using survey techniques with tests and measurements of basic technical skills in table tennis games for PTMSI Puslatkab Bangkalan athletes. Data analysis used percentage description. The results of the research on table tennis athletes at the Bangkalan puslatkab: basic service techniques $25 \%$ are in the adequate category and $75 \%$ are in the good category; basic attack techniques (attacking) 50\% in the less category and 50\% in the sufficient category; basic defense techniques (Block) 25\% are in the poor category, $50 \%$ are in the sufficient category and $25 \%$ are in the good category; basic technique of hitting (Drive) 50\% in the poor category, 25\% in the sufficient category, and1 25\% in the good category; the basic technique of push punch $75 \%$ is in sufficient category and 25\% is in good category; basic technique of flick blow 25\% in poor category, $50 \%$ in sufficient category, and $25 \%$ in good category; basic chop technique $75 \%$ is categorized as sufficient, and $25 \%$ is categorized as good. The conclusions of the study are the level of service technique skills (Serve) in good category, basic attack techniques (attacking) are between the less category and sufficient category, basic defense techniques (Block) are in sufficient category, basic blow techniques (Drive) are in poor category, basic techniques for push punches are categorized as enough, basic flick technique is categorized enough, and basic chop technique is categorized enough. Suggestions that can be given are the addition of hours and a proportional training program to improve mastery of the basic techniques of table tennis.
\end{abstract}

Keywords: basic technique; table tennis; Puslatkab Bangkalan

Accepted: $26^{\text {th }}$ of January 2022

Correspondence author: Khoirul Anwar, STKIP PGRI Bangkalan, Indonesia. E-Mail: khoirul@stkippgribkl.ac.id

DOI http://dx.doi.org/10.31851/hon.v5i1.6821 d

\section{(c) (1) (2)}

Jurnal Halaman Olahraga Nusantara licensed under a Creative Commons Attribution-ShareAlike 4.0 International License

\section{INTRODUCTION}

The national education system has been regulated in Constitution No. 20

Th 2003. In detail the regulations are written that the administration of education 
is given full responsibility to always uphold the principles and principles of democracy. Prioritizing justice and not acting discriminatory which must always refer to the values that exist in society. Values that are upheld in providing education include religious values, cultural values and the value of basic human rights. This is because Indonesia has a lot of pluralistic characteristics.

Students get the same forum and opportunity to develop their talents and potential as a provision for self-actualization. Of course, the forum in question does not leave the essence of education as a form of effort to make changes for the better in the sense that it can include learning achievements in knowledge, skills and in terms of affection. The right container will make students gain meaningful knowledge. The goal is that they can apply knowledge in everyday life (Arisman et al., 2021).

Especially in physical education, the skills and abilities of students or athletes are prioritized. The synergy between cognitive and psychomotor abilities can be designed and developed through a good training menu. In addition to this, training in a moral and sportsmanlike spirit should also be given balanced training. The development of athletes is certainly expected to be able to master the training load that has been given with a conscious effort to acquire basic abilities and character formation. The function of basic skills can support the growth of motion and physical development.

The District Training Center Program (PUSLATKAB) aims to add and improve the ability and basic movement skills of sports. One of the sports that is under the guidance of the puslatkab is table tennis. Several athletes were trained to receive training according to the instructions of the Bangkalan Indonesian National Sports Committee (KONI). The athletes are prepared to take part in the Provincial Sports Week (Proprov).

As an effort to prepare table tennis athletes, the puslatkab pays attention to the development of the athletes' abilities. This is to reduce the failure rate during the game. Many factors affect the failure of an athlete including time constraints and facilities. This is also explained by (Rachman et al., 2017) who also found 
problems that affect the success of table tennis athletes, including the less than optimal process, inadequate training facilities and infrastructure, and the less optimal training process. The training focused on techniques, tactics and strategies as well as understanding the rules of the table tennis game (Okilanda et al., 2021). This is very important so that the athlete can play well and the chances of winning the match increase. The Puslatkab team should have prepared various tools to test and measure the skills of its athletes. This has been done by (Indrawan \& Herliana, 2019) who have developed a smash skill test instrument in the table tennis game in the City of Tasikmalaya area. Therefore, it is necessary to have clear monitoring and adequate descriptions to see the basic technical skills of table tennis games for PTMSI Puslatkab Bangkalan athletes.

\section{METHOD}

Descriptive quantitative research was chosen to look at the survey results and describe the basic technical skills of table tennis. The sample that became the subject of this study were 4 athletes who were in the training of the puslatkab. The sample selection using the saturated sample technique, then all athletes as subjects were recorded and described the basic technical skills of the table tennis game.

Measuring the skill level of the basic table tennis game techniques, namely Serving, Attacking, Blocking, Drive Blowing, Pushing, Flicking, and Chop Techniques for athletes at the Bangkalan sports center using tests and measurements. Researchers collected data using a survey technique with tests and measurements of basic technical skills in table tennis games for PTMSI Puslatkab Bangkalan athletes.

After the data is obtained, then it is analyzed by converting it in the form of a percentage. Categorization in levels as follows:

Table 1. Scale Category

\begin{tabular}{cc}
\hline Range & Category \\
\hline <Mean to -1,5 SD & Very Poor \\
Mean -1,5 SD to Mean -0,5 SD & Poor \\
Mean -0,5 SD to Mean +0,5 SD & Medium \\
Mean +0,5 SD to Mean +1,5 SD & Good \\
>Mean +1,5 SD & Very Good \\
\hline
\end{tabular}


To get descriptive statistics, the data obtained is converted in the form of a percentage using the following formula:

Description:

$$
\mathrm{P}=\mathrm{F} / \mathrm{N} \times 100
$$

P : Percentage

$\mathrm{F}:$ Frequency

$\mathrm{N}$ : Number of Respondents

\section{RESULT AND DISCUSSION}

\section{Serve}

The serve score obtained from the basic skill data of table tennis service techniques for PTMSI Puslatkab Bangkalan athletes which displays 4 athletes can be seen in the following table:

Table 2. Frequency Distribution of Serve Skills

\begin{tabular}{ccccc}
\hline No & Norms & Category & Frequency & Persentage \\
\hline 1 & $<37,54$ & Very Poor & 0 & $0 \%$ \\
2 & 37,54 to 41,98 & Poor & 0 & $0 \%$ \\
3 & 41,98 to 46,42 & Enough & 1 & $25 \%$ \\
4 & 46,42 to 50,86 & Good & 3 & $75 \%$ \\
5 & $>50,86$ & Very Good & 0 & $0 \%$ \\
& Total & & 4 & $100 \%$ \\
\hline
\end{tabular}

Based on the table above, it can be seen that there were 0 athletes $(0 \%)$ who had basic service technical skills in the very poor category, 0 athletes $(0 \%)$ in the poor category, 1 athlete $(25 \%)$ in the sufficient category, 3 athletes $(75 \%)$ in the good category and 0 athletes $(0 \%)$ were categorized as very good. The analysis, if presented in graphical form, will be illustrated as follows:

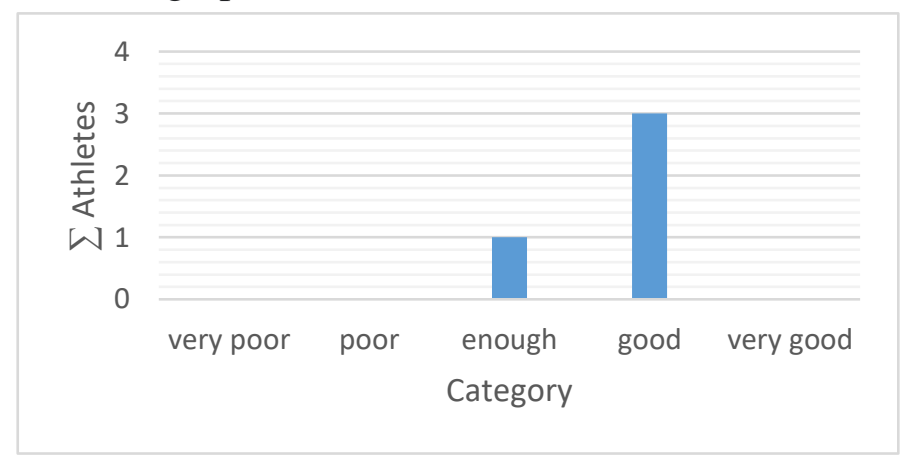

Figure 1. Skills of basic serve 


\section{Attack Technique}

Attack technique scores (attacking) obtained from basic skill data on table tennis service techniques for PTMSI Puslatkab Bangkalan athletes, totaling 4 athletes, can be seen in the following table:

Table 3. Frequency Distribution of Attack Technique Skills (Attacking)

\begin{tabular}{ccccc}
\hline No & Norms & Category & Frequency & Persentage \\
\hline 1 & $<37,54$ & Very Poor & 0 & $0 \%$ \\
2 & 37,54 to 41,98 & Poor & 0 & $0 \%$ \\
3 & 41,98 to 46,42 & Enough & 1 & $25 \%$ \\
4 & 46,42 to 50,86 & Good & 3 & $75 \%$ \\
5 & $>50,86$ & Very Good & 0 & $0 \%$ \\
& Total & & 4 & $100 \%$ \\
\hline
\end{tabular}

Based on the table above, it can be seen that there are 0 athletes $(0 \%)$ who have basic attack technique skills (attacking) in the very poor category, 2 athletes $(50 \%)$ in the poor category, 2 athletes $(50 \%)$ in the sufficient category, 0 athletes $(0 \%)$ in good category and 0 athletes $(0 \%)$ in very good category. The analysis, if presented in graphical form, will be illustrated as follows:

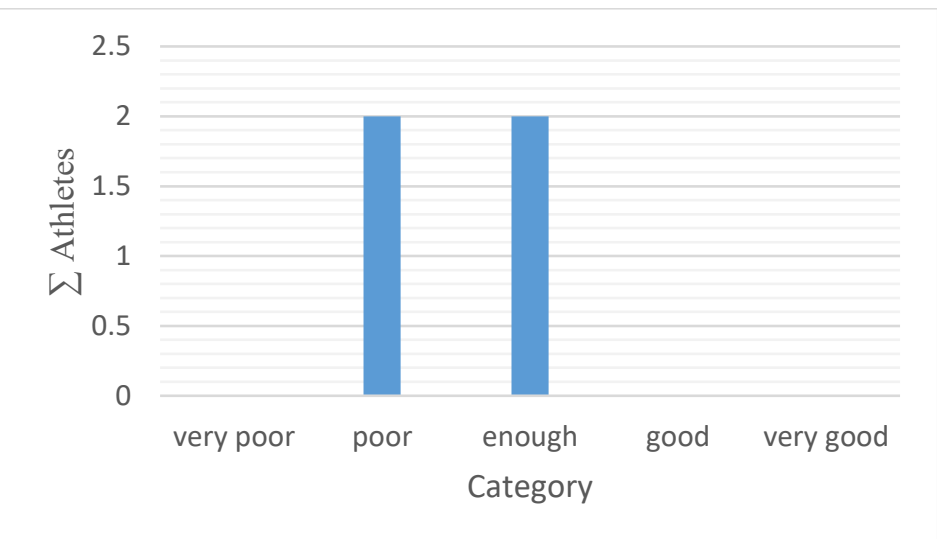

Figure 2. Skills of Attack Techniques (Attacking)

\section{Defense Techniques (Block)}

Defense technique scores (blocks) obtained from the basic skill data of table tennis service techniques for PTMSI Puslatkab Bangkalan athletes, totaling 4 athletes, can be seen in the following table: 
Table 4. Frequency Distribution of Defense Technique Skills (Block)

\begin{tabular}{ccccc}
\hline No & Norms & Category & Frequency & Persentage \\
\hline 1 & $<37,54$ & Very Poor & 0 & $0 \%$ \\
2 & 37,54 to 41,98 & Poor & 1 & $25 \%$ \\
3 & 41,98 to 46,42 & Enough & 2 & $50 \%$ \\
4 & 46,42 to 50,86 & Good & 1 & $25 \%$ \\
5 & $>50,86$ & Very Good & 0 & $0 \%$ \\
& Total & & 4 & $100 \%$ \\
\hline
\end{tabular}

Based on the table above, it can be seen that there are 0 athletes $(0 \%)$ who have basic defense technical skills (Block) in the very poor category, 1 athlete $(25 \%)$ in the less category, 2 athletes $(50 \%)$ in the sufficient category, 1 athlete (25\%) in good category and 0 athletes $(0 \%)$ in very good category. The analysis, if presented in graphical form, will be illustrated as follows:

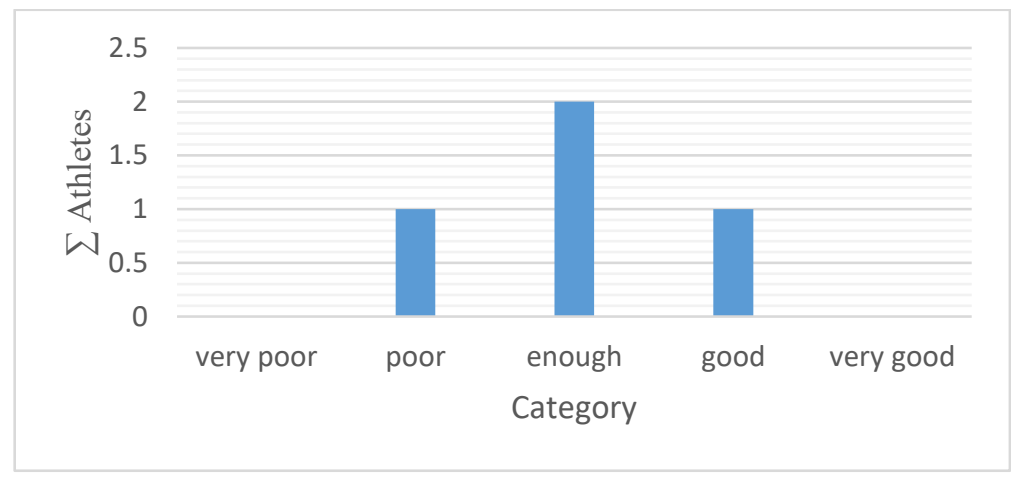

Figure 3. Defense Techniques Skills (Block)

\section{Drive Punch Technique}

The score of the stroke technique (drive) obtained from the basic skill data of table tennis service techniques for PTMSI Puslatkab Bangkalan athletes, totaling 4 athletes, can be seen in the following table:

Table 5. Frequency Distribution of Stroke Technique Skills (Drive)

\begin{tabular}{ccccc}
\hline No & Norms & Category & Frequency & Persentage \\
\hline 1 & $<37,54$ & Very Poor & 0 & $0 \%$ \\
2 & 37,54 to 41,98 & Poor & 2 & $50 \%$ \\
3 & 41,98 to 46,42 & Enough & 1 & $25 \%$ \\
4 & 46,42 to 50,86 & Good & 1 & $25 \%$ \\
5 & $>50,86$ & Very Good & 0 & $0 \%$ \\
& Total & & 4 & $100 \%$ \\
\hline
\end{tabular}


Based on the table above, it can be seen that there are 0 athletes (0\%) who have basic hitting technique skills (Drive) in the very poor category, 2 athletes $(50 \%)$ in the less category, 1 athlete $(25 \%)$ in the sufficient category, 1 athlete $(25 \%)$ in good category and 0 athletes $(0 \%)$ in very good category. The analysis, if presented in graphical form, will be illustrated as follows:

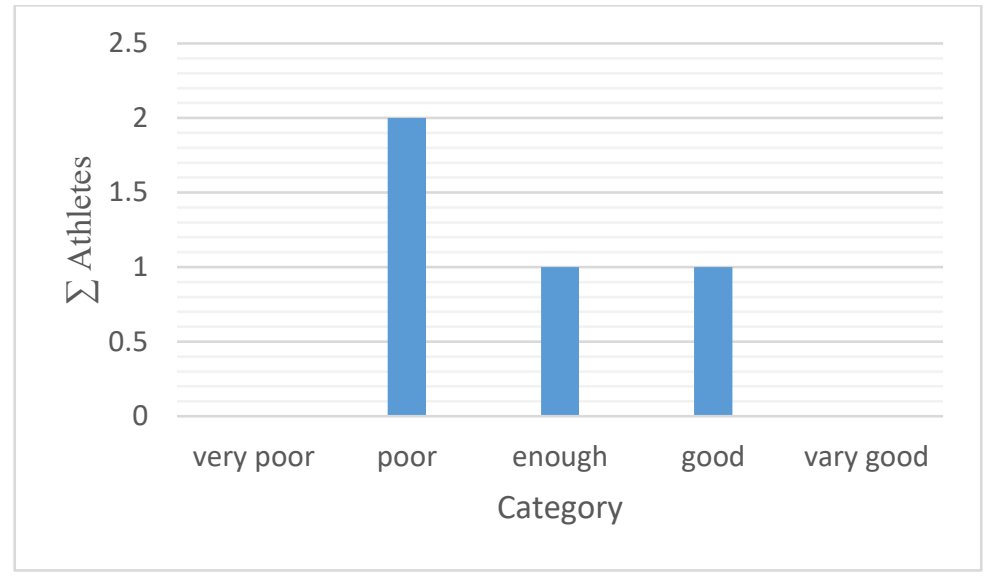

Figure 4. Drive Technique Skills

\section{Push Punch Technique}

The push stroke technique scores obtained from the basic skill data of table tennis service techniques for PTMSI Puslatkab Bangkalan athletes, totaling 4 athletes, can be seen in the following table:

Table 6. Frequency Distribution of Push Punch Technique Skills

\begin{tabular}{ccccc}
\hline No & Norms & Category & Frequency & Persentage \\
\hline 1 & $<37,54$ & Very Poor & 0 & $0 \%$ \\
2 & 37,54 to 41,98 & Poor & 0 & $0 \%$ \\
3 & 41,98 to 46,42 & Enough & 3 & $75 \%$ \\
4 & 46,42 to 50,86 & Good & 1 & $25 \%$ \\
5 & $>50,86$ & Very Good & 0 & $0 \%$ \\
& Total & & 4 & $100 \%$ \\
\hline
\end{tabular}

Based on the table above, it can be seen that there are 0 athletes $(0 \%)$ who have basic push technique skills in the very poor category, 0 athletes $(0 \%)$ in the poor category, 3 athletes $(75 \%)$ in the sufficient category, 1 athlete $(25 \%)$ in the good category. and 0 athletes $(0 \%)$ in very good category. The analysis, if presented in graphical form, will be illustrated as follows: 


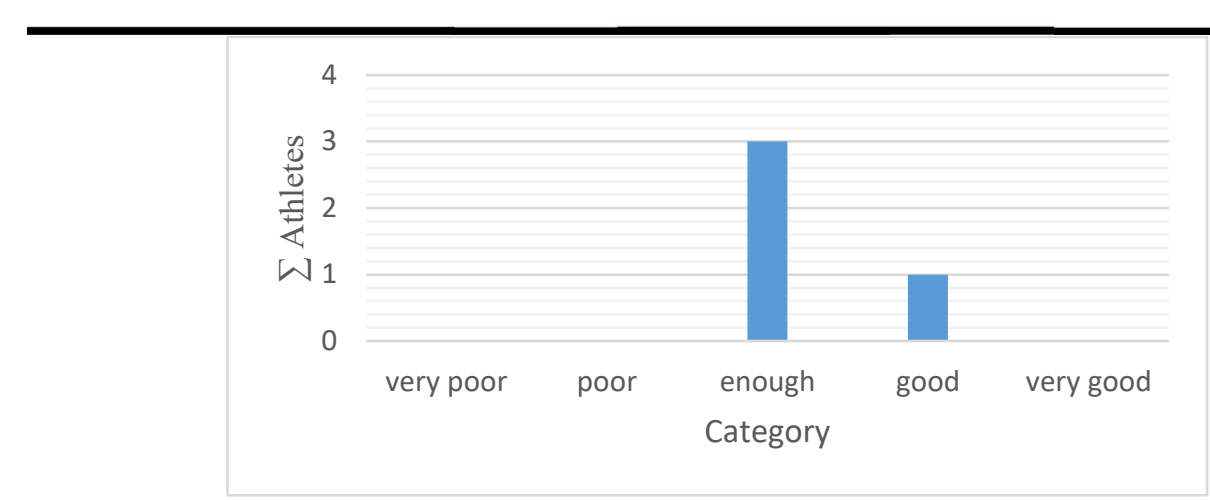

Figure 5. Push Punch Technique Skills

\section{Flick Technique}

Flick technique scores obtained from the basic skill data of table tennis service techniques for PTMSI Puslatkab Bangkalan athletes, totaling 4 athletes, can be seen in the following table:

Table 7. Frequency Distribution of Flick Technique Skills

\begin{tabular}{ccccc}
\hline No & Norms & Category & Frequency & Persentage \\
\hline 1 & $<37,54$ & Very Poor & 0 & $0 \%$ \\
2 & 37,54 to 41,98 & Poor & 1 & $25 \%$ \\
3 & 41,98 to 46,42 & Enough & 2 & $50 \%$ \\
4 & 46,42 to 50,86 & Good & 1 & $25 \%$ \\
5 & $>50,86$ & Very Good & 0 & $0 \%$ \\
& Total & & 4 & $100 \%$ \\
\hline
\end{tabular}

Based on the table above, it can be seen that there are 0 athletes $(0 \%)$ who have basic flick technique skills in the very poor category, 1 athlete $(25 \%)$ in the poor category, 2 athletes (50\%) in the sufficient category, 1 athlete $(25 \%)$ in the good category. and 0 athletes $(0 \%)$ in very good category. The analysis, if presented in graphical form, will be illustrated as follows:

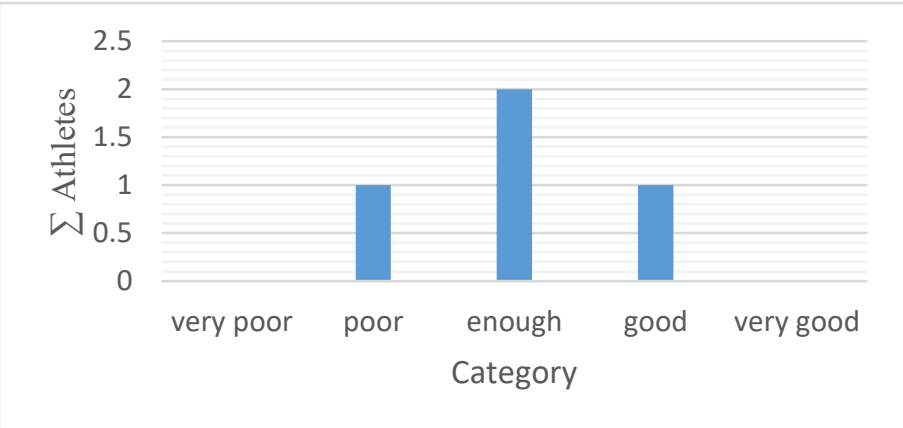

Figure 6. Flick Blow Technique Skills 


\section{Chop Technique}

The chop technique scores obtained from the basic skill data of table tennis service techniques for PTMSI Puslatkab Bangkalan athletes, totaling 4 athletes, can be seen in the following table:

Table 8. Frequency Distribution of Chop Technique Skills

\begin{tabular}{ccccc}
\hline No & Norms & Category & Frequency & Persentage \\
\hline 1 & $<37,54$ & Very Poor & 0 & $0 \%$ \\
2 & 37,54 to 41,98 & Poor & 0 & $0 \%$ \\
3 & 41,98 to 46,42 & Enough & 3 & $75 \%$ \\
4 & 46,42 to 50,86 & Good & 1 & $25 \%$ \\
5 & $>50,86$ & Very Good & 0 & $0 \%$ \\
& Total & & 4 & $100 \%$ \\
\hline
\end{tabular}

Based on the table above, it can be seen that there were 0 athletes $(0 \%)$ who had basic chop technique skills in the very poor category, 0 athletes $(0 \%)$ in the poor category, 3 athletes $(75 \%)$ in the sufficient category, 1 athlete $(25 \%)$ in the good category and 0 athletes $(0 \%)$ were categorized as very good. The analysis, if presented in graphical form, will be illustrated as follows:

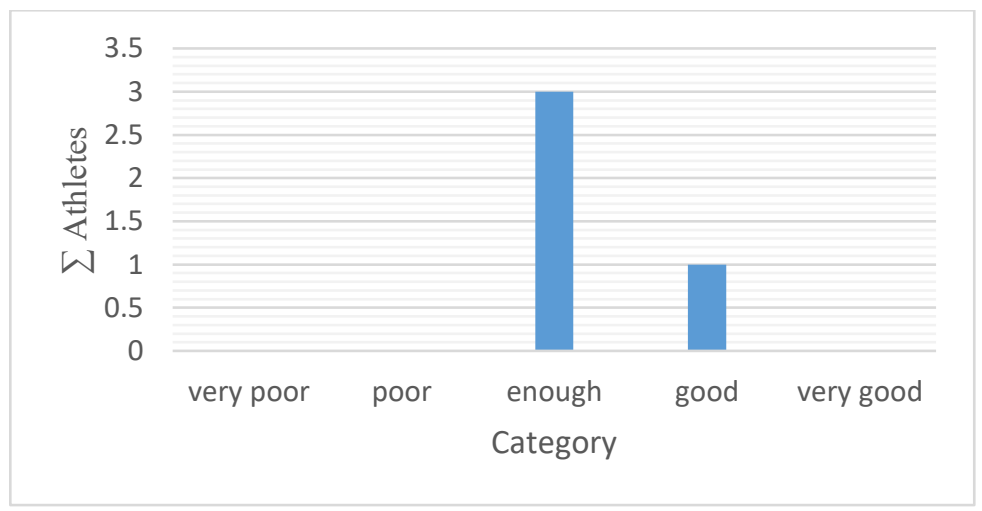

Figure 7. Chop Technique Skills

\section{Discussion}

The categorization has described the basic technical skill level of table tennis. It is clear that all the basic techniques measured have not touched the very good category. Whereas puslatkab is expected to be a forum to achieve certain results from an athlete. Of course, the intended result is an increase in mastery of skills. The higher the skill level, it is certain that the increased success of an athlete will be directly proportional to the personal quality of the athlete (Putra et 
al., 2020). These skills are not disturbed in terms of movement coordination. This is also confirmed by (Asri et al., 2017) that athletes who have a low level of eyehand coordination will have difficulty in learning and deepening table tennis game techniques. In line with that (Fuchs et al., 2018) explains that table tennis in theory has techniques and strategies including performance index, simulative approach, momentum analysis, and footwork analysis.

To improve coordination requires appropriate training in order to be optimal. There are many techniques that can stimulate athletes, one of which is by practicing a lot of balls. Opinion (Mu'ammar, 2017) strengthens this assumption, where his research found that a group of table tennis athletes who have high coordination is more appropriate if trained with a drill in varying target directions, while a group of table tennis athletes who have low coordination is better if trained with this method. constant target direction drill (Nopianto et al., 2020). To improve the basic skills of athletes in addition to movement coordination also requires precision training. Accuracy practice aims to increase the points earned (ARISMAN \& Okilanda, 2020). Like the breakthrough made by (Herliana, 2019) who found a variety of exercises to produce accuracy such as the forehand, they should try to apply the form of exercise using two tables.

The athlete's internal factors such as motivation are no less important. Remembering motivation is self-motivation that encourages individuals to do something better. Such as research findings (Islamy, 2017) which discusses the effect of the interaction between training methods and achievement motivation on topspin smash skills in table tennis. So it is undeniable that achievement motivation is needed by an athlete. This will relate to the ability to measure yourself based on experience. In line with that (Santosa \& Soegiyanto, 2016) also emphasized that table tennis achievements cannot be achieved speculatively, but must go through intensive training with the right training program and supported by appropriate technology. In the end, a series of training programs that have been prepared require evaluation to see the level of success. (Rihtiana \& Tomoliyus, 2014) also have the same opinion that in addition to the training program, 
evaluation also has an important role in the athlete development process (Okilanda et al., 2018).

\section{CONCLUSION}

The conclusions of the study are the level of service technique skills (Serve) in good category, basic attack techniques (attacking) are between the less category and sufficient category, basic defense techniques (Block) are in sufficient category, basic blow techniques (Drive) are in poor category, basic techniques for push punches are categorized as enough, basic flick technique is categorized enough, and basic chop technique is categorized enough. Suggestions that can be given are the addition of hours and a proportional training program to improve mastery of the basic techniques of table tennis.

\section{REFERENCES}

ARISMAN, A., \& Okilanda, A. (2020). Pengembangan Diri Melalui Olahraga Panahan. Jurnal MensSana. https://doi.org/10.24036/jm.v5i1.138

Arisman, A., Okilanda, A., Dwiansyah Putra, D., \& El Cintami Lanos, M. (2021). Resistensi Yoga dalam Meningkatkan Konsentrasi Ketepatan Memanah. Jurnal Patriot, 3, 71-81. https://doi.org/10.24036/patriot.v

Asri, N., Soegiyanto, \& Mukarromah, S. B. (2017). Pengaruh Metode Latihan Multiball dan Koordinasi Mata Tangan terhadap Peningkatan Keterampilan Forehand Drive Tenis Meja. Journal of Physical Education and Sport, 6(2), 179-185.

Fuchs, M., R., L., I., M. L., G., M., G., S., S., T., K., Y., H., Z., \& M., L. (2018). Table tennis match analysis: a review. J Sports Sci., 32(23), 2653-2662.

Herliana, M. N. (2019). Pengaruh Bentuk Latihan Menggunakan Dua Meja Terhadap Ketepatan Forehand Dalam Permainan Tenis Meja. Journal of SPORT (Sport, Physical Education, Organization, Recreation, and Training), 3(2), 93-97. https://doi.org/10.37058/sport.v3i2.1127

Indrawan, B., \& Herliana, M. N. (2019). Instrumen Keterampilan Smash Dalam Permainan Tenis Meja. Jurnal Pendidikan Jasmani Dan Olahraga, 53(9), 1689-1699.

Islamy, N. F. (2017). Pengaruh Metode Latihan Dan Motivasi Berprestasi Terhadap Keterampilan Smash Topspin Tenis Meja. Juara, 2(1), 66-76. https://doi.org/10.33222/juara.v2i1.33

Mu'ammar, M. (2017). Pengaruh metode latihan drill dan koordinasi terhadap ketepatan servis tenis meja. Jurnal Keolahragaan, 5(1), 63. https://doi.org/10.21831/jk.v5i1.12805 
Nopianto, W., El Cintami Lanos, M., \& Arisman, A. (2020). The Effect of Mixed Inpact Aerobic Gymnam on The Improvement of Physical Fitness for High School. JIPES, 6(2), 55-61.

Okilanda, A., Arisman, A., Lestari, H., Lanos, M. E. C., Fajar, M., Putri, S. A. R., \& Sugarwanto, S. (2018). Sosialisasi Petanque Sebagai Olahraga Masa Kini. Jurnal Bagimu Negeri, 2(1), 69-76. https://doi.org/10.26638/jbn.638.8651

Okilanda, A., Dlis, F., Humaid, H., Putra, D. D., Arisman, A., \& Muslimin, M. (2021). Defense Warm-Up Exercise Material for 13-Age Athlete Using Video Technology in Covid-19 Era. International Journal of Human Movement and Sports Sciences, 9(4), 629-634. https://doi.org/10.13189/saj.2021.090404

Putra, D. D., Okilanda, A., Arisman, A., Lanos, M. E. C., Putri, S. A. R., Fajar, M., Lestari, H., \& Wanto, S. (2020). Kupas Tuntas Penelitian Pengembangan Model Borg \& Gall. Wahana Dedikasi : Jurnal PkM Ilmu Kependidikan, 3(1), 46. https://doi.org/10.31851/dedikasi.v3i1.5340

Rachman, I., Sulaiman, \& Rumini. (2017). Pengembangan Alat Pelontar Bola Tenis Meja (Robodrill IR-2016) Untuk Latihan Drill Teknik Pukulan Drive Dan Spin. Journal of Physical Education and Sports, 6(1), 50-56.

Rihtiana, V., \& Tomoliyus, T. (2014). Pengembangan Instrumen Penilaian Keterampilan Teknik Forehand Dan Backhand Drive Tenis Meja Pada Atlet Usia Dini. Jurnal Keolahragaan, 2(2), 216-227. https://doi.org/10.21831/jk.v2i2.2627

Santosa, T., \& Soegiyanto. (2016). Pengambangan Alat Bantu Return Board Untuk Forehand Topspin Tenis Meja. Jurnal Pedagogik Keolahragaan, 02(02), 30-48. 